UDC 347.736.6

DOI https://doi.org/10.32849/2663-5313/2021.9.06

Oleh Syniehubov,

Doctor of Law, Associate Professor, Head, Poltava Regional State Administration, 45, Sobornosti street, Poltava, Ukraine, postal code 36014, sinegubov.oleg@gmail.com

ORCID: orcid.org/0000-0001-6362-3115

Syniehubov, Oleh (2021). Efficiency of insolvency practitioners in realizing legitimate expectations of the parties to a bankruptcy case. Entrepreneurship, Economy and Law, 9, 37-46, doi: https://doi.org/10.32849/2663-5313/2021.9.06

\title{
EFFICIENCY OF INSOLVENCY PRACTITIONERS IN REALIZING LEGITIMATE EXPECTATIONS OF THE PARTIES TO A BANKRUPTCY CASE
}

Abstract. The purpose is to determine areas for improving the performance of insolvency practitioners and ensuring the accomplishment of bankruptcy proceedings by an insolvency practitioner. Research methods. The article is based on general scientific and special methods of scientific cognition. Results. The author has studied areas for improving the efficiency of implementing bankruptcy proceedings considering a pivotal role of insolvency practitioners, who are authorized by the state to satisfy legal expectations of creditors and a debtor. A protected object in bankruptcy cases is creditors' property rights guaranteed by the Convention for the Protection of Human Rights and Fundamental Freedoms. This stipulates a duty of the state to establish a judicial procedure that permits the national courts to consider cases effectively, in a fair manner, and within a reasonable time. It has been found that in securing the interests of parties to a bankruptcy case, insolvency practitioners are neither private or official actors when exercising the functions of arbitration management: they exercise public functions delegated by the court. The payment system of basic remuneration given actual authority should be revised to provide insolvency practitioners with an inducement to work efficiently. Conclusions. The improvement of the performance of insolvency practitioners is determined by: a random assignment by the automation system, which should take into account their reputation, qualification, experience in a specific economic activity that affects their independence; the need for substantiating deprivation of an insolvency practitioner; creditors' control over forming the bankruptcy estate. The insolvency practitioner's exercise of public functions stipulates a positive responsibility of the state for his activity and the availability of balanced and effective control means, keeping in mind regulations of Art. 13 of the Convention for the Protection of Human Rights and Fundamental Freedoms.

Key words: insolvency practitioner, remuneration and cost reimbursement of insolvency practitioner, assignment and deprivation of insolvency practitioner.

\section{Introduction}

The objective of the commercial procedure is to protect violated, unrecognized or disputed rights and legitimate interests of individuals and legal entities and the state effectively, such as the restoration, renewal, recognition of the right that may occur through adhering to the requirements of fairness, impartiality, and timeliness of the consideration of cases referred by the law to the jurisdiction of commercial courts. Bankruptcy proceedings are specific in this context. According to the preamble of the Code of Ukraine on Bankruptcy Procedures (hereinafter referred to as "CUBP") (Kodeks Ukrainy z protsedur bankrutstva), restoration of the solvency of a corporate debtor or declaration of its bankruptcy is carried out to satisfy creditors' demands by applying bankruptcy proceedings provided by CUBP (Postanova u spravi № 905/2030/19). The objective of relevant proceedings also involves striking a balance between public and, in particular, state interests, the interests of creditors, a debtor, insolvency practitioners, and other parties to bankruptcy cases through subjecting the debtor to various statutory procedures (Aseeva N.V., 2013).

The object of protection in bankruptcy cases are property rights guaranteed by Art. 1 of Protocol No. 1 to the Convention, which stipulates the state duty to ensure a judicial procedure that permits national courts to hear cases effectively, in a fair manner, and within a reasonable time (Sovtransavto Holding v. Ukraine). A tangible-legal aspect of legitimate expectations in transnational and national law 
enforcement and interpretive practice of applying Art. 1 of Protocol No. 1 to the Convention is recognized as "property", the right to claim or the right to expect an "asset", future property benefit, or the good of an economic value (Slipchenko S. O. (2020), p. 73; Maidanyk R.A., 2019; Maidanyk R.A., 2020; Spasibo-Fateeva, I.V., Krat, V.I., \& Pechenyj O.P., et al., 2011) and is the object of civil rights (Sokurenko V.V., 2021). The person's legitimate expectation of "asset" in the interpretative regard of Art. 1 of Protocol No. 1 to the Convention will depend on the existence of a supposed procedure that will allow the person to present his own position and be heard. The procedural aspect of expectations of the parties to a case, as partially defined above, specifies procedural means designed to protect the subjective right or the right of expectation. The means must meet the objectives of commercial litigation and its principles that may affect the achievement of the purpose of bankruptcy proceedings as a form of commercial litigation: restoring the debtor's solvency or efficient protection of rights, interests, including legitimate expectations of creditors in which their receivables from a debtor are transformed in case of his insolvency that is intermediated in the organizational relations of participation in the meeting of creditors and the creditors' committee, which should ensure an option of influence on the protection of the right guaranteed by Art. 1 of Protocol 1 to the Convention (Syniehubov O.V., 2021).

Determining functions related to the implementation of solvency restoration procedures are entrusted to solvency practitioners, who shall guarantee the effectiveness of bankruptcy proceedings. Therefore, the procedure and criteria for their selection, appointment, control means of their activity, creation of a reasonable system of checks and balances given the proportionality principle, removal, selection of other specialists by a practitioner, and appointment of new practitioners in the case have an impact on the efficiency of protection of creditors' claims or debtor's solvency restoration. At the same time, the above can mitigate or eliminate the influence of subjective and "human factors", prevent abuse and illegal actions of insolvency practitioners, respond to errors or ineffective actions, which constitute the content of bankruptcy procedures, promptly.

Issues of the effectiveness of bankruptcy proceedings and the activity of insolvency practitioners within bankruptcy proceedings were the subject of researches by $\mathrm{O}$. A. Belianevych, O. M. Biriukova, O. M. Borieiko, V. V. Hurtovoho, A. A. Butyrskoho, I. A. Butyrskoi, S. V. Zhukova, Yu. V. Kabenoiuk, V. Ya. Pohrebniaka, B. M. Poliakova, P. D. Pryhuzy,
O. O. Stepanova, B. V. Yarynko, and others. Representatives of modern doctrine and practice point out a lot of problems associated with various procedures involving insolvency practitioners, as well procedures for their appointment, removal, determination of remuneration of insolvency practitioners.

The purpose of the article is to identify areas for improving the performance of insolvency practitioners and ensuring the accomplishment of an objective of bankruptcy proceedings by an insolvency practitioner: meeting creditors' claims with maximum consideration of the debtor's and public interests or restoring the debtor's solvency.

Methodology. The study highlights essential doctrinal and applied issues of a search for effective legal means of improving the efficiency of arbitration management, determining the legal status of an insolvency practitioner. Keeping in mind the purpose of the research, the author uses methods that have allowed identifying the relevant areas: analysis and synthesis, systems analysis, induction and deduction, formal legal and comparative legal methods, etc.

The study is based on a systems approach, which involves studying the ways of legal influence on the conduct of insolvency practitioners that are statutorily rendered in the ways of their appointment, removal, and payment of remuneration. Systems analysis and synthesis have made it possible to gradually elucidate the inner nature and impact of bankruptcy proceedings on the legal expectations of their participants. In view of this, their role in the system is covered. Systems and structural-functional analyses have allowed specifying a legal status of insolvency practitioners, establishing the means of control over their activities, identifying ways of improving the current legislation regulating bankruptcy procedures.

2. Determining the efficiency of the appointment of insolvency practitioners

The European Bank for Reconstruction and Development (the EBRD) presented the generalized procedure for appointing insolvency practitioners in different countries, as follows: creditors appoint an insolvency practitioner in about a third of the world, a court in another third (Germany, Bosnia and Herzegovina, Egypt, Morocco, and Tunisia ), about a quarter of countries conduct appointments randomly following different ways (France, Ukraine, Macedonia, China, Hungary, Serbia, the Slovak Republic, and Slovenia; the Republic of Lithuania pays paid to the nature of business and its size); in other countries, there are various mixed procedures, in particular, the appointment by a court based on the recommendation or by creditors (Bulgaria, Macedonia, Moldova, 
Romania, Estonia); the initial appointment may be random with an option of appointing, or subsequent selection of another person (Germany) There are countries where a special state body appoints an insolvency practitioner (Kazakhstan, Latvia, and Croatia) (Donchenko O. 2019; Brydzh K., 2014).

According to the EBRD, an insolvency practitioner appointed to conduct an insolvency case may influence its form and outcome. Despite the financial risks which the creditors face in the case of incompetent management of the bankruptcy estate or debtor's business, creditors are often not allowed to take part in appointing insolvency practitioners actually or effectively. This order is consistent to prevent abuse on the part of creditors but may forfeit creditors' credibility in the procedure and incentives to active participation (Brydzh K., 2014). The current legislation provides for a differentiated approach to appointing, the provisions of which are enshrined in Art. 28 of CUBP.

As for the random selection of insolvency practitioners, researches show that appointment via an automated system may seem objective but, at the same time, may lead to "accidental" results - in most cases, it does not allow identifying a specialist professionally relevant to a particular insolvency case (given business kind and specific industry, the amount of debt, form of ownership, enterprise size). The reputation of an insolvency practitioner is essential for the effectiveness of bankruptcy proceedings and bona fide debtors and creditors. In a random selection, the appointment is not based on the professional achievements of insolvency practitioners that may deprive them of incentives to perform well at work. The consideration of reputation, professional qualities of insolvency practitioners under their appointment is likely to affect their good faith when exercising their powers to keep up reputation (Brydzh K., 2014).

The effectiveness of bankruptcy proceedings is affected by factors related to the competence of insolvency practitioners, taking into account experience and qualification. Under current law, an insolvency practitioner may have an economic or legal education. At the same time, education and experience are critical to bankruptcy proceedings, in particular, the experience of crisis management. In terms of the liquidation procedure, the insolvency practitioner with legal education can be competent enough, considering the involvement of an assistant and the option of attracting specialists in the field of financial and economic, technical knowledge, etc. In the case of reorganization, an insolvency practitioner having experience in crisis management of a particular economic sector, a good reputation (the Qualification Com- mission can provide the relevant data based on international and domestic ratings) is more likely to conduct the procedure professionally. If creditors are interested in appointing a specialist with a high reputation, then, expecting his solid performance, they should be statutorily entitled to offer increased remuneration to the manager, which will contribute to his integrity, avoidance of shady schemes in bankruptcy proceedings.

The survey of business representatives shows that executives and top managers note that in case of their bankruptcy or status of the creditor of an insolvent business entity, they would focus on integrity, honesty, the reputation of an insolvency practitioner, and his expertise in the branch specifics of the enterprise regardless of whether the restoration of solvency or liquidation procedure takes place.

Therefore, the legislation should provide for a differentiated approach to selection and payment for the professional services of an insolvency practitioner, incl. appointed by a complex randomized selection of an automated system, that would take into account the above provisions. However, the appointment procedure should exclude influence on the selection. This concerns not only a technical aspect but also a legal one: there must be specified restrictions on attempts and rejections of insolvency practitioners proposed by the automated system.

The current randomized order of appointing a specific insolvency practitioner to perform the powers of an administrator of an estate and restructuring manager at the initial stages of the procedure as a way to exclude subjective influence on his activities may be discredited by the creditor committee's right to suspend the insolvency practitioner from duties (para. 4 of Art. 28 of CUBP). The process of reforming bankruptcy proceedings does not always mean working legislative proposals. The draft law "On Amendments to the Code of Ukraine on Bankruptcy Procedure (on the status of an insolvency practitioner)" (Proekt Zakonu pro vnesennia zmin do Kodeksu Ukrainy z protsedur bankrutstva) denies the creditors' committee the opportunity to influence the removal of an insolvency practitioner through applying to the court. These provisions create additional risks of abuse on the part of the insolvency practitioner, and the obligation of proving his inefficiencies or abuses creates further complications for creditors in protecting their legitimate expectations.

According to the EBRD, enabling the most interested parties (creditors), who are within an ace of the maximum losses of property caused by the insolvency of their debtors, to participate in appointing an insolvency practitioner can 
contribute to rising competition and improvement of the performance of insolvency practitioners. At the same time, the appointment procedure should ensure, if possible, the exclusion of subjectivity in selecting an administrator (Brydzh K., 2014). A truly independent and competent insolvency practitioner with a high reputation can ensure the efficiency of the formation of the bankruptcy (liquidation) estate and its fair distribution. The appointment of an objectively independent insolvency practitioner not affiliated with parties to bankruptcy proceedings promotes the purpose of bankruptcy proceedings (Konstantynov D, 2021)

To maintain a system of balances under the removal of an insolvency practitioner at the request of the creditors' committee, the request must be motivated and justified. However, the deprivation of creditors of the right to replace the insolvency practitioner at any stage of bankruptcy proceedings means an almost uncontrolled activity of the latter, considering that the commercial court must be independent and only evaluates the validity of doubts about the due performance of the insolvency practitioner's functions.

Judgments on the removal of insolvency practitioners are not subject to a separate appeal to the Supreme Court (para. 1, part 3 of Art. 9 of CUBP), but the relevant complaints can be added to the cassation appeals against decisions that are subject to appeal in cassation (para. 2, part 3 of Art. 9 of CUBP) (Postanova u spravi № 922/3369/19). The case law has two directions in this context: the petition of the creditors' committee is a sufficient ground for the removal of an insolvency practitioner regardless of its grounds and justification in the petition; the creditors' committee shall state in the petition the sound reasons for removing the insolvency practitioner, and the court shall establish their existence to prevent the violation of requirements of the principle of independence of insolvency practitioners. The Supreme Court holds the position that the creditors' committee is not obliged to specify grounds for removal in its petition. However, if the creditors' committee has put forward arguments in favor of removal, in particular, provided for in sub-paras. 1-6, para. 2, p. 4 of art. 28 of CUBP, the court must check them, which is a condition for rendering a judicial decision, and check procedure compliance in general (procedure for convening and conducting meetings and/or creditors' committee, the legality of its formation, etc.), as well as take measures for preventing abuse of procedural rights. The Supreme Court did not resolve the latter issue noting that the exercise of the relevant right by the creditors' com- mittee does not confirm an abuse of the procedural right (Shabarovskyi B., 2021). In this respect, the Supreme Court fulfilled its function of the unity of case law (Shylo O.H., 2020).

In removing insolvency practitioners, the Commercial Court should proceed, in particular, from the tasks of commercial litigation. If the insolvency practitioner's commission of repeated, gross intentional violations in a specific case or other bankruptcy cases is confirmed by the fact that judgments took legal effect (on removal, the recognition of actions illegal, the invalidity of costs incurred), this may indicate the justification of doubts about the competence, integrity, or independence of the insolvency practitioner.

3. Remuneration of insolvency practitioners

Based on the provisions of Art. 30 of CUBP, it is identified the procedure for calculating the remuneration and reimbursement of expenses of an insolvency practitioner. These rules generate a good deal of ambiguous interpretations in the theory and practice of bankruptcy. This concerns the fairness of the fixed amount of remuneration, the determination of its proportionality to the activities performed by the insolvency practitioner, and the effectiveness of his activities. The rules of bankruptcy law in almost all countries of the world establish the principle of payment of remuneration of the insolvency practitioner depending on his performance: in proportion to the satisfied claims of creditors at their expense and on the extent of repaid claims.

According to the position of the Supreme Court, in the absence of assets of the bankrupt, which may cover the services and expenses of the insolvency practitioner, payment should be made at the expense of creditors (Postanova u spravi № 05/5026/1809/2012). Keeping in mind the proportion of the votes of creditors to the number of their monetary claims, the court is entitled to apply the principle of proportionality to the distribution of costs between creditors if there are no funds from the sale of the debtor's property for liquidation (Postanova $u$ spravi № 265/26-02/14/13-08). The Supreme Court also established the position that the sources of payment for the services of the insolvency practitioner are not dependent on the property status of the initiating creditor in the bankruptcy case, his legal status (entity based on private or public ownership, government agency, public organization, etc.), as well as sources of financing of a certain creditor (Postanova u spravi № 05/5026/1809/2012). When initiating bankruptcy proceedings, creditors, who get professional services from the insolvency practitioner and have a legit- 
imate expectation of the outcome of his activities (a receipt of "assets"), must be aware of their risks associated with the fact that in terms of bankruptcy proceedings, property and monetary funds for satisfying the debtor's property claims and covering expenses may not be found, and the insolvency practitioner has a legitimate (based on "the law") expectation to cover the proceedings, which is the burden of the insolvent debtor's creditors (Postanova $u$ spravi № 910/32824/15). At the same time, the legal certainty, which is a basis for the procedural aspect of creditors' legitimate expectations, highlights that they should not bear an excessive burden that can be determined through the proportionality of interests. According to the Supreme Court, payment for the services of an insolvency practitioner is not covered by the proceeds from the sale of the debtor's property or funds received from the debtor's production activities. It should be covered at the expense of creditors following the principle of proportionality to their monetary claims (Postanova $u$ spravi № 905/2030/19). In addition, these provisions require firm guarantees from creditors to control the activities of the insolvency practitioner.

Provisions of the current CUBP provide for the following sources of payment of the insolvency practitioner's remuneration: a cash advance for three months paid by the initiating creditor; funds from the economic activity of the bankrupt; funds received from the sale of assets, except the collateral. The relevant approach should motivate the replenishment of the liquidation estate and compliance with the terms of bankruptcy proceedings. Draft Law No. 2647 proposes to stipulate the obligation of creditors (in particular, based on a court decision) to pay the remuneration of the insolvency practitioner for the entire duration of bankruptcy proceedings, regardless of the results of his activities. These provisions do not meet the requirements of proportionality of repayment of creditors' claims.

In this context, the current procedure and one proposed in draft laws to CUBP for payment of the basic and additional remuneration of an insolvency practitioner should be revised in view of the following considerations. In particular, under Art. 30 of CUBP, the remuneration of insolvency practitioners is set for the exercise of their powers. The specific provisions state that the extent of remuneration for the performance of powers of an administrator of estate or liquidator, manager of reorganization, restructuring, sales is fixed in different amounts bound to the minimum salary and the average monthly salary of the debtor's manager for each month of performance. In practice, these provisions are implemented in a manner that insolvency practitioners receive the basic remuneration for being a party to the bankruptcy case without taking into account the due exercise of the powers vested in them by the state. The mentioned circumstances must be taken into account when reforming the laws regulating remuneration. Remuneration should be set depending on the powers exercised (piece-rate form of reward grounded on approved tariffs or an hourly rate, the amount of which should be set and approved when appointing an insolvency practitioner) and assessment of their effectiveness and bona fides by relying on a report to be approved by the parties to a case interested in bankruptcy proceeding and commercial court. If there is a dispute between an insolvency practitioner and the parties to the case about the extent of remuneration, the assessment of the performance and real and reasonable time spent during his activities may be based on an audit of bankruptcy proceedings - a party to the case insisting on the inefficiency of the insolvency practitioner should apply to the commercial court. Moreover, the audit may be conducted for other purposes, in particular, to assess the effectiveness of bankruptcy proceedings in using property assets of the debtor. Audit tasks may involve: verification of the financial data rendered in the report of the insolvency practitioner; assessment of the insolvency practitioner regarding the establishment of the bankruptcy (liquidation) estate; check of the balance sheet of the business entity during restructuring, liquidation, etc.; verification of the validity and justifiability of the costs of bankruptcy proceedings, etc.

4. Control over insolvency practitioners

The efficiency of insolvency practitioners is dependent on the nature, degree of control over their activities, direct and indirect (stimulating) influence. The EBRD recommends that the countries, which it invests, permit creditors to affect the level of remuneration of insolvency practitioners, but with consideration of the nature and complexity of the work performed. Given that activities of insolvency practitioners, as a rule, are covered by the debtor's bankruptcy estate, countries must have a legal framework regulating the issue of monetary remuneration, and the relevant tariff system should be transparent, truly objective, flexible, ensure a sufficient level of remuneration for the efficiency of an insolvency practitioner, avoiding the danger of excessive remuneration in cases in which the satisfactory indicators in the formation of the bankruptcy (liquidation) mass are not achieved. The payment of a basic remuneration of the insolvency practitioner for his position and receipt of official data on 
requests from legal entities, public authorities, etc., from state registers, convening a meeting, or the committee of creditors without finding assets is burdensome for creditors or debtors. Remuneration should depend solely on the effectiveness of repayment of creditors' claims, which guarantees the right to form a bankruptcy (liquidation) estate.

The effectiveness of bankruptcy proceedings also depends on the ability of creditors to influence the formation of the bankruptcy (liquidation) mass as parties interested in the outcome of bankruptcy proceedings. According to Draft Law No. 2647, the creditors' rights are narrowed that may cause the renewal of mechanisms for delaying bankruptcy proceedings, as it stipulates the sale of the debtor's property without taking into account their will. It is also proposed to fix an additional remuneration in percentage correlation of the insolvency practitioner, which will reduce the amount of funds received by a creditor, out of the will of the secured creditor and the determination of the maximum amount.

The current CUBP enshrines pro-creditor interests and the right of creditors to outline the terms of sale of the debtor's property, as they are interested in its disposal at the highest price. Draft laws to CUBP propose to reduce the creditors' means of influence on the sale of the debtor's property. The legislation grants the committee of creditors and secured creditors the powers to agree on the sale of property, generation of lots, and stipulation of terms of sale of the debtor's property (para. 8 of art. 48 CUBP: consent to the sale of the debtor's property and approval of the terms of sale of the debtor's property (except for the property that is the subject of security) in the reorganization proceedings under the reorganization plan or bankruptcy procedure). The draft law proposes to deprive secured creditors and creditors of the right to set agree on the terms of sale of the debtor's property and to empower insolvency practitioners and the court. It is submitted to deprive the committee of creditors and a secured creditor (art. 75 of CUBP) of the right to set (agree on) the terms of tender and lots. At the same time, para. 46 of the draft law No. 4409 authorizes a liquidator to sell total assets of a bankrupt in the form of a single property complex or several single property complexes in the manner prescribed by CUBP (Proekt Zakonu pro vnesennia zmin do Kodeksu Ukrainy z protsedur bankrutstva). Relevant provisions lay grounds for abuses due to the option of artificial reduction of the cost of the liquidation estate. The formation of lots can be carried out in such a way that the demand for the debtor's property can be minimized, an opportunity for asset buyout, e.g., by its final beneficiary, is opened. The devaluation of the bankruptcy (liquidation) estate may take place, in particular, through putting on auction real estate located in different regions and of different designated use as a single lot, introducing illiquid property as a part of a single property complex into a lot that artificially reduces the cost of valuable assets in its composition (Korobkova O., 2021). Setting the sale price and agreeing on the terms of sale of the debtor's property with the consent of creditors can reduce corruption risks during bankruptcy proceedings. Current legislation fairly laid down clear regulations for establishing the initial price of the re-auction with the consent of a secured creditor or the creditors' committee (para. 5 of Art. 79 of CUBP).

5. Legal nature of arbitration management and its efficiency

A topical issue to be resolved within the framework of ensuring the efficiency of insolvency practitioners, which has not gained unity of positions in civil, economic, administrative, procedural doctrines, concerns the legal status of an insolvency practitioner and the legal nature of arbitration management. The settlement of the above issue will affect the legal nature of control over insolvency practitioners and the substantiation of state responsibility for their actions.

The need for the availability of administrative law procedures for the specific control can be motivated by their underperformance and good faith in bankruptcy proceedings. This refers to various types of participants' abuse in bankruptcy proceedings, which are claimed by practitioners (Kovalenko V., 2006). For effective legal regulation, it is necessary to specify the legal nature of arbitration management and the professional activities of insolvency practitioners. If an insolvency practitioner does not have the status of an enterprise official, an employee, then it is about the delegation of public functions rather than ordinary professional activities, because the procedure for declaring bankruptcy plays a pivotal role in maintaining domestic investment climate and public interests, the effectiveness of which affects the protection of legitimate expectations of a debtor and creditors. Intentional offenses and the abuse of rights by insolvency practitioners shall entail some legal penalties.

Creditors, commercial court and a debtor exert procedural control over the implementation of measures prescribed by para. 2 of art. 12 of CUBP, as well as the absence of abuses on the part of insolvency practitioners in the exercise of their rights under para. 1 of art. of CUBP, and submission of truthful information to the court. Any of these entities must initiate an audit of activities of the insolvency 
practitioner in case of violation of reasonable deadlines for discharge of creditors' claims and provisions consolidated in para. 2 of art. 12 of CUBP. Administrative control is entrusted, in particular, to the Ministry of Justice, State Fiscal Service, public - to the self-regulatory organization of insolvency practitioners, disciplinary - to the Qualification Commission. In this regard, it is reasonable to refer to the experience of Germany, where courts shall compile a list of lawyers competent and legally qualified to carry out bankruptcy proceedings. An individual who is independent of creditors, a debtor, and is well versed in economic affairs can become an insolvency practitioner. The selection of a specific insolvency practitioner meets the needs of the relevant procedure, and thus, there is no randomized system (Iarynko B.V., 2019; Poliakov B. M. (Eds.), 2008).

In different areas of national doctrine, arbitration management and the status of an insolvency practitioner are determined through the exercise of public-law functions, or organizational (as an enterprise official for a reorganization manager and liquidator), or as a professional service provider. In this context, Draft Law No. 2647 abolishes the rule according to which an insolvency practitioner (a reorganization manager or liquidator) is equated to an official of the corporate debtor that limits the possibility of bringing the insolvency practitioner to criminal liability for failure to perform organizational and administrative-economic functions. The issue of who is responsible for the activities of a corporate debtor during the reorganization or liquidation when the head is removed and the administrator is not an official remains unsettled. Therefore, it is impossible to bring the insolvency practitioner to the statutory liability for his culpable neglect or undue performance of organizational or administrative-economic functions during the exercise of the powers of the reorganization manager or liquidator of the corporate debtor. At the same time, the actions of the manager, as a person who abused his powers in carrying out the professional activities of the insolvency practitioner, can be qualified under Art. 365-2 of the Criminal Code of Ukraine. If the insolvency practitioner does not have the status of a corporate official, the state must provide other effective means of control and responsibility of insolvency practitioners based on the performance of their public functions. An essential means of monitoring the efficiency of an insolvency practitioner is an audit, which any party to the bankruptcy case can request. In recognizing the activities of arbitration management not as a professional service but a public function, an audit should be conducted by the State Audit Service. An audit is also a means of establishing the effectiveness of the performance of an insolvency practitioner. In this context, the author once again draws attention to the need for conducting an audit of the professional activities of arbitration management. If audit data indicate abuses, wastage of the bankruptcy (liquidation) estate, they must be the basis for criminal proceedings.

In this regard, it is appropriate to refer to the case-law of the ECtHR. In the case of Kotov v. Russia, the ECtHR found a violation of Article 1 of Protocol No. 1 to the Convention in 2010. Due to the illegal actions of the bank insolvency practitioner, the complainant did not receive funds which are bank indebtedness under the statutory principle of proportional distribution of assets among creditors of one queue. The amount awarded by the courts could be regarded as the complainant's "property" under Article 1 of Protocol No. 1 to the Convention. When distributing the assets among "privileged" creditors before other first-queue creditors, the insolvency practitioner acted illegally, and thus, the complainant did not receive his funds. The ECtHR stated that the insolvency practitioner illegally affected the complainant's right to property protection - a monetary obligation of the bank that was in the process of winding up. The ECtHR noted that the state holds responsibility for the wrongful acts of its representative (the insolvency practitioner) and should provide a mechanism that will make it possible to control one's activities effectively (Kotov v. Russia, 2010). Over time, in 2012, the ECtHR revised its decision and specified that the complainant was permitted to defend his violated rights, and the State fulfilled its obligations according to Art. 1 of Protocol No. 1 to the Convention. Consequently, the complainant's rights had not been violated. At the same time, five of the seventeen judges considered that Article 1 of Protocol No. 1 had been violated. They relied on the caselaw of the European Court, according to which the State is responsible to citizens for the actions of individuals (Kotov v. Russia, 2012).

The ECtHR emphasized that an insolvency practitioner is a representative of the state. However, it is essential to have regard to his status specified in the bankruptcy law, which sets out the requirements for candidates for the position of an insolvency practitioner and qualities he must possess but does not explain whether the administrator is an individual or an official. The ECtHR considers that if the law provisions refer to an individual, then the state cannot be granted an absolute discharge given his exercise of administrator's powers and court delegation of such duties (Costello Roberts in United Kingdom, § 27). The Court should supervise this process (the opposite example in the ECtHR 
ruling in the case (Katsiuk v. Ukraine, § 39) under which the liquidator has no any features of a "governmental body" in the sense of Art. 34 of the Convention, because the fact of appointment of the liquidator and approval of his report by the commercial court does not give him the status of a state body). The insolvency practitioner acts under state control while performing statutory powers (Luordo v. Italy, § 67-69). Therefore, from the standpoint of the ECtHR and given circumstances of the case, actions or inaction of the insolvency practitioner stipulate the responsibility of the state (Sychev v. Ukraine, $\S 53,54)$, not for violation of Art. 6 of the Convention but failure to provide effective procedural means under Art. 13 of the Convention. A state which delegates public functions of carrying out bankruptcy proceedings to an insolvency practitioner cannot be discharged responsibility for the inefficiency of his activities.

\section{Conclusions}

Given the crucial role of insolvency practitioners in ensuring legitimate expectations in bankruptcy proceedings and their effectiveness, the main concepts for further reform of the legislation regulating the relevant relations should involve: ensuring the independence and competence of insolvency practitioners during their appointment, and thus, they should be appointed solely on a random basis at the ini- tial stage and after removal; the randomized system should have regard to the reputation of a specialist, a type and branch of economic activity of the business entity, enterprise size, ownership form, the amount of debt; substantiation of the notice of removal of an insolvency practitioner; creditors' control over the formation of the bankruptcy estate; the implementation of public functions by an insolvency practitioner determines the responsibility of the state for his activities and the availability of proportionate and effective means of control, taking into account the provisions of Art. 13 of the Convention, one of which may be an audit of the activities of the insolvency practitioner.

An insolvency practitioner has a legitimate expectation of covering the costs of the procedure and payment of remuneration for his activities, if it is carried out effectively (based on the "law" of expectation), which is a burden of creditors (a creditor) of the insolvent debtor that must be moderate and justified. The relevant remuneration should be determined by the proportion of the actions taken during the exercise of powers within arbitration management to the creditors' satisfied claims. These provisions stipulate the development of another remuneration system, which is agreed between an insolvency practitioner and the creditors' committee, as well as approved by the court.

\section{References:}

1. Kodeks Ukrainy $\mathrm{z}$ protsedur bankrutstva [Bankruptcy Code of Ukraine] 18.10.2018 № 2597-VIII. Retrieved from https://zakon.rada.gov.ua/laws/show /2597-19\#Text (in Ukrainian).

2. Postanova u sprazi № 905/2030/19 [2017], Verkhovnyi sud [Decision in the case No. 905/2030/19 [2017] of the Supreme Court]. Retrieved from https://ips.ligazakon.net/document/view/C013542?ed=2020 $0603 \&$ an $=79$ (in Ukrainian).

3. Aseeva, N.V. (2013). Obespechenie chastnyh i publichnyh interesov pri bankrotstve predprijatija [Securing private and public interests in the bankruptcy of the company]. Doneck: DonUJeP (in Ukrainian).

4. Sovtransavto Holding v. Ukraine, Apl. No. 48553/99, Judgment 25.7.2002 (European Court of Human Rights). Retrieved from http://hudoc.echr.coe.int/fre?i=002-5236.

5. Slipchenko S. O. (2020). Poniattia zakonnykh ochikuvan yak riznovydu maina [The concept of legitimate expectations as a kind of property]. Forum Prava - Forum Law, 3, pp.66-76 (in Ukrainian)

6. Maidanyk, R.A. (2019). Rechove pravo: pidruchnyk [Property law: a textbook]. Kyiv : Alerta (in Ukrainian)

7. Maidanyk, R.A. (2020). Pravomirni ochikuvannia yak mainove pravo: praktyka YeSPL, pravo Ukrainy, inshykh yevropeiskykh krain [Legitimate expectations as property law: the practice of the European Court of Human Rights, the law of Ukraine and other European countries.]. Pravomirni ochikuvannia - Legitimate expectations. I. V. Spysybo-Fatieievoi (Ed.). Kharkiv : EKUS, pp.92-97 (in Ukrainian).

8. Spasibo-Fateeva, I.V., Krat, V.I., \& Pechenyj, O.P. et al. (2011). Har'kovskaja civilisticheskaja shkola: ob\#ekty grazhdanskih prav: monografija [Kharkiv civil law school: objects of civil rights: monograph]. I.V. Spasibo-Fateeva (Ed). Har'kov: Pravo [in Ukrainian].

9. Sokurenko, V. V. (2021). Lehitymni ochikuvannia yak obiekt tsyvilnykh prav i sudovoho zakhystu za praktykoiu YeSPL [Legitimate expectations as an object of civil rights and judicial protection in the case law of the European Court of Human Rights]. Problemy tsyvilnoho prava ta protsesu : tezy dop. uchasnykiv nauk.-prakt. konf., prysviach. 96-y richnytsi vid dnia narodzhennia O.A. Push- 
kina - Problems of civil law and process: theses add. participants of scientific-practical. conf., dedicated. 96th anniversary of the birth of OA Pushkin (pp.74-76). Kharkiv : KhNUVS (in Ukrainian).

10. Syniehubov, O.V. (2021). Teoretychni ta praktychni aspekty zabezpechennia zakhystu pravomirnykh ochikuvan pid chas zdiisnennia protsedur bankrutstva [Theoretical and practical aspects of ensuring the protection of legitimate expectations during bankruptcy proceedings]. Nove Ukrainske pravo. Aktualni problemy pryvatnoho prava - New Ukrainian law. Current issues of private law, 3, pp.90-102 (in Ukrainian).

11. Donchenko, O. (2019) Analiz efektyvnosti vypadkovoho vyboru yak harantii nezalezhnosti arbitrazhnoho keruiuchoho [Analysis of the effectiveness of random selection as a guarantee of independence of the arbitral trustee]. Zastosuvannia norm Kodeksu Ukrainy z protsedur bankrutstva - Application of the norms of the Bankruptcy Procedure Code of Ukraine. S. V. Zhukov (ed.). (pp. 143-151) K.: Alerta (in Ukrainian).

12. Brydzh, K. (2014). Institut arbitrazhnyh upravljajushhih po delam o nesostojatel'nosti: novoe issledovanie EBRR s analizom prav kreditorov v delah o nesostojatel'nosti [Insolvency Trustees Institute: New EBRD Study Analyzing Creditors' Rights in Insolvency Cases]. Pravo na etape perekhoda onlain - Online transition eligibility, 2, pp.2-14 (in Ukrainian).

13. Proekt Zakonu pro vnesennia zmin do Kodeksu Ukrainy z protsedur bankrutstva (shchodo statusu arbitrazhnoho keruiuchoho) [Draft Law on Amendments to the Bankruptcy Procedure Code of Ukraine (concerning the status of an arbitration trustee)] № 2647 20.12.2019. Retrieved from http://w1.c1.rada.gov.ua/pls/zweb2/webproc4_1?id=\&pf3511=67733 (in Ukrainian).

14. Konstantynov, D (2021). Yak zrobyty arbitrazhnykh keruiuchykh po-spravzhnomu nezalezhnymy [How to make arbitration trustees truly independent]. Retrieved from https://attorneys. ua/publication/how-to-make-the-receivers-genuinely-independent/ (in Ukrainian).

15. Postanova u spravi № 922/3369/19 [2021], Verkhovnyi sud [Decision in the case No. 922/3369/19 [2021] of the Supreme Court]. Retrieved from https://reyestr.court.gov.ua/ Review/98083109 (in Ukrainian).

16. ShabarovskyiB.(2021). UPDATE:chy mozhekomitetkredytorivvidstoronytyarbitrazhnoho keruiuchoho bez poiasnennia prychyn? [UPDATE: Can the creditors' committee remove the trustee without explanation?] Yurydychna hazeta - Legal newspaper. Retrieved from https://yur-gazeta. com/publications/practice/bankrutstvo-i-restrukturizaciya/update-chi-mozhe-komitet-kreditoriv-vidstoroniti-arbitrazhnogo-keruyuchogo-bez-poyasnennya-prichin.html (in Ukrainian).

17. Shylo, O. H. (2020). Rol Verkhovnoho Sudu v mekhanizmi zabezpechennia stalosti ta yednosti sudovoi praktyky: okremi aspekty [The role of the Supreme Court in the mechanism of ensuring the sustainability and unity of judicial practice: some aspects]. Visnyk Natsionalnoi akademii pravorykh nauk Ukrainy - Bulletin of the National Academy of Legal Sciences of Ukraine, 3, pp.128-142 (in Ukrainian).

18. Postanova $u$ spravi № 05/5026/1809/2012 [2017], Verkhovnyi sud [Decision in the case No.05/5026/1809/2012 [2017] of the Supreme Court]. Retrieved from https://reyestr.court.gov. ua/Review/79349053 (in Ukrainian).

19. Postanova $u$ spravi № 265/26-02/14/13-08 [2017], Verkhovnyi sud [Decision in the case No. 265/26-02/14/13-08 [2017] of the Supreme Court]. Retrieved from https://verdictum.ligazakon.net/document/73700072 (in Ukrainian).

20. Postanova $u$ spravi № 05/5026/1809/2012 [2017], Verkhovnyi sud [Decision in the case No. 05/5026/1809/2012 [2017] of the Supreme Court]. Retrieved from https://protocol.ua/ru/postanova_kgs_vp_vid_16_01_2019_roku_u_spravi_05_5026_1809_2012/(in Ukrainian).

21. Postanova $\bar{u}$ spravi № $\overline{9} 10 / 3 \overline{2} 8 \overline{2} 4 / 15$ [2017]], Verkhovnyi sud [Decision in the case No. 910/32824/15 [2017] of the Supreme Court]. Retrieved from https://verdictum.ligazakon.net/ document/79589196 [in Ukrainian].

22. Postanova u spravi № 905/2030/19 [2017], Verkhovnyi sud. [Decision in the case No. 912/1783/16 [2017] of the Supreme Court]. Retrieved from http://search.ligazakon.ua/1_doc2. nsf/link1/VS181529.html (in Ukrainian).

23. Proekt Zakonu pro vnesennia zmin do Kodeksu Ukrainy z protsedur bankrutstva zakonoproektu [Draft Law on Amendments to the Bankruptcy Code of Ukraine of the Bill] № 4409, 20.11.2020. Retrieved from http://w1.c1.rada.gov.ua/pls/zweb2/webproc4_1?pf3511=70493 (in Ukrainian).

24. Korobkova, O. (2021). Shcho ne tak iz novym kontseptom protsedury bankrutstva? [What's wrong with the new concept of bankruptcy?]. Retrieved from https://www.epravda.com.ua/columns/2021 /06/21/675198/ (in Ukrainian).

25. Kovalenko, V. (2006). Bankrutske dvovladdia ta zakonodavcha nevyznachenist [Bankrupt dual power and legislative uncertainty]. Dzerkalo tyzhnia - Mirror of the week. 39, p. 11 (in Ukrainian). 
26. Iarynko B.V. (2019). Administratyvno-pravovi zasady zdiisnennia kontroliu za diialnistiu arbitrazhnykh keruiuchykh [Administrative legal principles of control over the activities of arbitration trustees]. Candidate's thesis. Kyiv: NUBiP (in Ukrainian).

27. Poliakov, B. M. (Eds.). (2008). Rozghliad torhovykh (hospodarskykh) sprav v Ukraini ta Nimechchyni [Trail of trade (economic) cases in Ukraine and Germany]. K.: Lohos (in Ukrainian).

28. Kotovv.Russia[GC],Apl.54522/00,Judgment14.1.2010[GC].Retrievedfromhttps://hudoc. echr.coe.int/eng\#\{\%22dmdocnumber\%22:[\%22861041\%22]\%22itemid\%22:[\%22001-96709\%22]\} (in Russian).

29. Kotov v. Russia [GC], Apl. 54522/00, Judgment 3.4.2012 [GC]. Retrieved from http:// hudoc.echr.coe.int/app/conversion/pdf/?library=ECHR\&id=001-110023\&filename=001-110023. pdf (in Russian).

30. Costello Roberts v United Kingdom, Apl. 13134/87 [1993] ECHR 16 (25 March 1993) Retrieved from http://www.bailii.org/eu/cases/ECHR/ 1993/16.htm (in English).

31. Delo «Katsiuk protyv Ukrayni», Apl. 58928/00 05.04.2005 (Evropeiskyi sud po pravam cheloveka) [The case of Katsyuk v. Ukraine, Apl. № 58928/00 05.04.2005 (European Court of Human Rights)]. Retrieved from http://search.ligazakon.ua/ http://search.ligazakon.ua/1_doc2. nsf/link1/SO1279.html (in Ukrainian).

32. Luordo v. Italy, Judgment 17 July 2003. The European Court of Human Rights (First Section), Apl. 32190/96 Retrieved from https://www.legal-tools.org/doc/7059fd/pdf/ (in English).

33. Case of Sychev v. Ukraine, Apl. 4773/02, Judgment 11 October 2005 (European Court of Human Rights). Retrieved from https://international.vlex.com/vid/case-of-sychev-vukraine-26778166 (in English).

\section{Олег Синєгубов,}

доктор юридичнх наук, доцент, голова, Полтавська обласна державна адміністрачія, вулиия Соборності, 45, Полтава, Україна, індекс 36014, sinegubov.oleg@gmail.com

ORCID: orcid.org/0000-0001-6362-3115

\section{ЕФЕКТИВНІСТЬ ДІЯЛЬНОСТІ АРБІТРАЖНИХ КЕРУЮЧИХ У ЗАБЕЗПЕЧЕННІ ПРАВОМІРНИХ ОЧІКУВАНЬ УЧАСНИКІВ СПРАВИ ПРО БАНКРУТСТВО}

Анотація. Метою статті є визначення напрямів підвищення ефективності діяльності арбітражних керуючих та забезпечення арбітражним керуючим досягнення мети процедур банкрутства. Методи дослідження. Роботу виконано на підставі загальнонаукових і спеціальних методів наукового пізнання. Результати. Досліджено напрями підвищення ефективності здійснення процедур банкрутства з огляду на визначальну роль арбітражних керуючих, яка на них покладена державою, у забезпеченні правомірних очікувань кредиторів та боржника. Об'єктом захисту у справах про банкрутство є майнові права кредиторів, гарантовані Конвенцією про захист прав людини і основоположних свобод, яка зумовлює обов'язок держави забезпечити судову процедуру, що дає змогу національним судам ефективно, справедливо й у розумний строк розглядати справи. Визначено, що у процесі забезпечення інтересів сторін справи про банкрутство арбітражні керуючі під час здійснення функцій арбітражного управління є не приватними або службовими особами, а здійснюють публічні функції, які їм делеговані судом. 3 метою стимулювання арбітражних керуючих до ефективних результатів має бути переглянута система оплати основної винагороди залежно від фактично здійснених повноважень. Висновки. Підвищення ефективності діяльності арбітражних керуючих визначається такими ознаками: встановленням рандомізованого призначення автоматизованою системою, що вплине на їх незалежність, яка має враховувати їхню репутацію, кваліфікацію, досвід роботи в певній галузі господарської діяльності; необхідністю обгрунтування відсторонення арбітражного керуючого; контролем кредиторів над формуванням конкурсної маси. Здійснення арбітражним керуючим публічних функцій зумовлює позитивну відповідальність держави за його діяльність та наявність пропорційних, ефективних засобів контролю з огляду на вимоги ст. 13 Конвенції про захист прав людини і основоположних свобод.

Ключові слова: арбітражний керуючий, винагорода та відшкодування витрат арбітражного керуючого, призначення й відсторонення арбітражного керуючого.

The article was submitted 13.09.2021

The article was revised 05.10.2021

The article was accepted 26.10.2021 